Sains Malaysiana 48(5)(2019): 1025-1033

http://dx.doi.org/10.17576/jsm-2019-4805-11

\title{
Immobilization of Choline Chloride: Urea onto Mesoporous Silica for Carbon Dioxide Capture
}

(Pemegunan Kolina Klorida: Urea ke atas Silika Mesoliang untuk Penangkapan Karbon Dioksida)

\author{
Zaitun Ghazali, Nur Hasyareeda Hassan, Mohd Ambar Yarmo, Teh Lee Peng \& Rizafizah Othaman*
}

\begin{abstract}
A green composite adsorbent based on mesoporous silica-gel (SG) and deep eutectic solvent (DES) mixture of choline chloride-urea (ChCl:U) was synthesized as an alternative for carbon dioxide ( $\left.\mathrm{CO}_{2}\right)$ adsorption. The composite adsorbent was prepared by wet impregnation technique with various $\mathrm{ChCl:U}$ (mole ratio 1:2) content in $\mathrm{SG}$ at $5-15 \%$ (w/w). Fourier transform infrared attenuated total reflectance (ATR-FTIR) results showed successful impregnation of ChCl:U into SG with the presence of $\mathrm{C}=\mathrm{O}$ carbonyl amide group stretching, $\mathrm{N}$-H scissoring bending, $\mathrm{CH}_{2}$ bending and $\mathrm{C}-\mathrm{N}$ stretching peaks. Thermal degradation of the adsorbent started with urea at $130^{\circ} \mathrm{C}$ followed by $\mathrm{ChCl}$ at $300^{\circ} \mathrm{C}$. Meanwhile, nitrogen physisorption demonstrated a decrease in specific surface areas of the sorbents with increasing ChCl:U weight percentage due to the blockage of micropores by $\mathrm{ChCl}: \mathrm{U}$. The optimum $\mathrm{CO}_{2}$ adsorption capacity of $22.3 \mathrm{mg} / \mathrm{g}$ was achieved by $10 \% \mathrm{ChCl}: U / S G 200$, which was higher than the immobilised SG200, hence making it relevant to become a green and economical adsorbent for $\mathrm{CO}_{2}$ capture.
\end{abstract}

Keywords: Adsorption; carbon capture; choline chloride; deep eutectic solvent; silica gel; urea

\section{ABSTRAK}

Penjerap komposit hijau berasaskan gel silika mesoliang (SG) dan pelarut eutektik dalam (DES) kolina klorida-urea $(\mathrm{ChCl:U})$ disintesis untuk penjerapan karbon dioksida (CO). Penjerap komposit telah disediakan dengan teknik penjejalan basah dengan muatan 5-15\% (b/b) ChCl:U (nisbah mol 1:2). Spektrum inframerah transformasi Fourier-pantulan penuh kecil (ATR-FTIR) membuktikan bahawa ChCl:U telah berjaya dijejalkan ke atas $S G$ dengan kehadiran puncak regangan kumpulan karbonil amida $\mathrm{C}=\mathrm{O}$, bengkokan $\mathrm{N}-\mathrm{H}$, bengkokan $\mathrm{CH}_{2}$ dan regangan $\mathrm{C}-\mathrm{N}$. Suhu degradasi penjerap bermula dengan urea pada $130^{\circ} \mathrm{C}$ diikuti oleh $\mathrm{ChCl}$ pada $300^{\circ} \mathrm{C}$. Analisis penjerapan fizikal nitrogen menunjukkan penurunan luas permukaan dengan peningkatan peratus berat $\mathrm{ChCl:U}$ disebabkan mikroliang yang dilitupi oleh ChCl:U. Kapasiti penjerapan $\mathrm{CO}_{2}$ yang optimum $(22.3 \mathrm{mg} / \mathrm{g})$ tercapai dengan menggunakan 10\% ChCl:U/SG200 dengan kapasiti penjerapannya lebih tinggi berbanding SG200 tanpa pemegunan. Ini menjadikannya penjerap hijau yang ekonomi untuk penangkapan $\mathrm{CO}_{2}$.

Kata kunci: Gel silika; kolina klorida; pelarut eutektik dalam; penangkapan karbon; penjerapan; urea

\section{INTRODUCTION}

In this millennium era, global warming and climate change have become of the main environmental concerns. Based on the facts and data gathered from the atmosphere, seawater, rock, ice on poles and plants, it is clear that the earth is experiencing global warming (Creamer \& Gao 2015). Kyoto Protocol (1998) has listed carbon dioxide $\left(\mathrm{CO}_{2}\right)$ with other gases such as nitrous oxide $\left(\mathrm{N}_{2} \mathrm{O}\right)$, methane $\left(\mathrm{CH}_{4}\right)$ and sulfur hexafloride $\left(\mathrm{SF}_{6}\right)$ as greenhouse gases (Rao \& Riahi 2006) with the significant increase in the concentration of $\mathrm{CO}_{2}$ as a major cause of global warming (Vilarrasa-García et al. 201; Zhu et al. 2014). The Paris Climate Change Conference 2015 set the limit of global warming at below $2^{\circ} \mathrm{C}$ with only $1.5^{\circ} \mathrm{C}$ temperature rise. This agreement requires every country to reduce $\mathrm{CO}_{2}$ concentration in the atmosphere. Therefore, researchers are now exploring ways of reducing $\mathrm{CO}_{2}$ which include carbon capture study.
The most mature way for $\mathrm{CO}_{2}$ capture is by using aqueous alkanol amines. This technique has several drawbacks such high energy consumption in desorption process, equipment corrosion and high volatility (Marcus 2018; Zhu et al. 2018). Ionic liquid (IL) has also been studied as liquid absorbent with special properties such as low vapour pressure, good thermal stability, tunability and high $\mathrm{CO}_{2}$ solubility (Ramdin et al. 2012; Yusuf et al. 2018). However, its cost, toxicity, and poor biodegradability limit the application of IL as $\mathrm{CO}_{2}$ absorbent (Zhang et al. 2015). Recently, increasing attention has been paid to new green solvent, deep eutectic solvents (DES) as a promising alternative to replace amine-based technologies. DESs provide interesting advantages such as easy to prepare, biodegradable, low volatility, wide liquid range, water compatibility, low vapour pressure and biocompatible that are favourable in many possible green technologies including $\mathrm{CO}_{2}$ capture (Zhang et al. 2015). 
DES are generally obtained by mixing quaternary ammonium halide salts as hydrogen-bond acceptor (HBA) with hydrogen-bond donor (HBD) molecules at certain ratio. They are bonded through hydrogen bonds or metal halide bonds that result in lower melting point of the mixture compared to the individual components (Dai et al. 2013). Many types of DESs have been synthesized with various HBA:HBD molar ratio for $\mathrm{CO}_{2}$ capture purpose. Mixtures of choline chloride $(\mathrm{ChCl})$ or 2-hydroxy-N,N,N-trimethylethanaminium chloride and urea(U) are the most widespread chemicals used upon the design of DESs. Choline chloride:Urea (ChCl:U) are non-toxic, biocompatible, biodegradable, easy to prepare and inexpensive (Sarmad et al. 2017). Li et al. (2008) found that $\mathrm{CO}_{2}$ showed the highest solubility, 0.309 $\mathrm{mol}_{\mathrm{CO} 2} / \mathrm{mol}_{\mathrm{DES}}$ in choline chloride:urea $(\mathrm{ChCl}: \mathrm{U})(\mathrm{mole}$ ratio 1: 2) at $313 \mathrm{~K}$ and $12.5 \mathrm{MPa}$. Su et al. (2009) in their study, using $\mathrm{ChCl}: \mathrm{U}: \mathrm{H}_{2} \mathrm{O}$ (mole ratio $1: 2: 1$ ) found that the solubility of $\mathrm{CO}_{2}$ was $0.2694 \mathrm{~mol}_{\mathrm{CO} 2} / \mathrm{kg}_{\mathrm{DES}}$, at $313.15 \mathrm{~K}$ and $350 \mathrm{KPa}$ pressure. Meanwhile, Leron et al. (2013) reported that the $\mathrm{CO}_{2}$ solubility in $\mathrm{ChCl}$ :Urea was higher than $\mathrm{ChCl}$ :glycerol and $\mathrm{ChCl}$ :ethylene glycol (Leron \& Li 2013. Sarmad et al. (2017) investigated the $\mathrm{CO}_{2}$ solubility of various type of DES based on ammonium and phosphonium salt as HBA. They reported that the synthesized DESs had higher $\mathrm{CO}_{2}$ solubility and lower viscosity than conventional IL. Those findings have given promising insights on the potential of DESs as solvent for $\mathrm{CO}_{2}$ capture.

However, high viscosity of liquid $\mathrm{ChCl}: \mathrm{U}$ requires high pressure environment for maximum $\mathrm{CO}_{2}$ absorption that can lead to increasing operational cost. In addition, DES and other solvents in liquid form at room temperature are difficult to manage. Liquid adsorption material integrated with porous solid materials as supporter can overcome this problem (Gray et al. 2012; Hu et al. 2017). This integration has promising remarks that may increase $\mathrm{CO}_{2}$ adsorption capacity. An example of effective adsorbent is silica gel (SG). Silica are materials having high surface area that can be applied in various applications (Abdullah et al. 2017; Jon et al. 2013). The existence of micro and meso pores, high thermal stability and excellent in regeneration process of $\mathrm{SG}$ are beneficial for $\mathrm{CO}_{2}$ adsorbent. However, past studies showed that the $\mathrm{CO}_{2}$ adsorption capacity on SG surface is still low especially at atmospheric temperature and pressure (Yu et al. 2011). Thus, modification of SG through immobilization liquid absorbent, specifically in this study with $\mathrm{ChCl}: \mathrm{U}$ would be recommended to enhance the $\mathrm{CO}_{2}$ adsorption capacity.

In this work, solid adsorbents from impregnated choline chloride:urea $(\mathrm{ChCl}: \mathrm{U})$ onto silica were synthesized using simple wet impregnation method. The effect of $\mathrm{ChCl}: \mathrm{U}$ percentage loading on the surface functional group, thermal stability, the surface properties and pore structure of adsorbents were investigated. The adsorbents were screened in terms of their $\mathrm{CO}_{2}$ adsorption capacity at $25^{\circ} \mathrm{C}$ and $1 \mathrm{~atm}$.

\section{Materials AND METHODS}

\section{MATERIALS}

Choline chloride, $\mathrm{ChCl}(\geq 98 \%$, Sigma Aldrich) and urea, $\mathrm{U}(\geq 99 \%$, Merck) were obtained from Aldrich Chemistry. The support materials used in this work were microporous and mesoporous commercial Silica Gel 60 purchased from Merck with particle size in the range of $0.200-0.063 \mathrm{~mm}$. All materials used as received without further purification. Pure nitrogen and carbon dioxide gases (purity> 99.0\%) were obtained from Ply Gas Company, Malaysia.

\section{PREPARATION METHOD}

Synthesis of Adsorbents DES was prepared by mixing $\mathrm{ChCl}$ and $\mathrm{U}$ in the molar ratio of 1:2. Both compounds were predried in the oven at $100^{\circ} \mathrm{C}$. The mixture was heated up to $80^{\circ} \mathrm{C}$ and continuously stirred for $2 \mathrm{~h}$ until homogeneous colourless liquid was obtained. The liquid formed was then transferred into a well-sealed bottle and kept in desiccator. Composite materials $\mathrm{ChCl}: \mathrm{U} / \mathrm{SG}$ were prepared using wet impregnation method. Prior to impregnation, SG was calcined at $200^{\circ} \mathrm{C}$ for $4 \mathrm{~h}$ to remove moisture. Twenty $\mathrm{mL}$ of ethanol was added to the specified amount of 0.1-0.3 g $\mathrm{ChCl}: \mathrm{U}$ and the solution was gently stirred until dissolved. Afterwards, 1.7-1.9 g of SG was added to the initial mixture followed by stirring for $4 \mathrm{~h}$ at room temperature in a closed system. Then, the mixture was sonicated for $5 \mathrm{~min}$ at 5 amplitudes, $3 \mathrm{~W}$ and $1600 \mathrm{~J}$ by S 4000-010 Sonicator 4000. After that, the mixture was dried at $80^{\circ} \mathrm{C}$ for $6 \mathrm{~h}$ to eliminate volatile compound. SG200, $5 \% \mathrm{ChCl}: \mathrm{U} / \mathrm{SG} 200$, $10 \% \mathrm{ChCl}: \mathrm{U} / \mathrm{SG} 200$ and $15 \% \mathrm{ChCl}: \mathrm{U} / \mathrm{SG} 200$ were the final adsorbent products. Dried adsorbents were kept in sealed bottle in a desiccator before further characterization.

Characterization The presence of surface functional groups was determined using Perkin Elmer Attenuated Total Reflectance-Fourier Transform Infrared (ATRFTIR) spectrometer in the range of $600-4000 \mathrm{~cm}^{-1}$. Thermogravimetric analysis (TGA) and Differential Thermogravimetric analysis (DTG) were performed for all samples using Mettler Toledo TGA/SDTA 851. Surface area and porosity properties of the samples were characterized using $\mathrm{N}_{2}$ physisorption at $77 \mathrm{~K}$ over Micromeritics ASAP 2020 instrument. Prior to analysis, the samples were degassed at $100^{\circ} \mathrm{C}$ for $5 \mathrm{~h}$ to remove the moisture and adsorbed gas. In this work, Brunauer, Emmet and Teller (BET) method was used to obtain the surface area. Pore volume and pore size distribution were determined by Barret-Joyner-Halenda (BJH) method. Pore size distribution for sorbents was computed using Barret-Joyner-Halenda (BJH) to determine the mesopores filling mechanism.

\section{$\mathrm{CO}_{2}$ ADSORPTION EVALUATION}

The adsorption and desorption isotherms of $\mathrm{CO}_{2}$ were carried out using Micromeritics ASAP 2020 instrument by replacing $\mathrm{N}_{2}$ gas with $\mathrm{CO}_{2}$ gas at room temperature 
and atmospheric pressure. Pure $99 \% \mathrm{CO}_{2}$ was used and equipped with circulating water to control the temperature. The interaction between $10 \% \mathrm{ChCl}: \mathrm{U} / \mathrm{SG}$ and $\mathrm{CO}_{2}$ was studied using fluidized-bed reactor with glass column. Approximately $1.0 \mathrm{~g}$ of the adsorbent was purged with nitrogen $\left(\mathrm{N}_{2}\right)$ and heated at $100^{\circ} \mathrm{C}$ for $1 \mathrm{~h}$ to remove moisture content and humidity followed by exposure to $99.9 \%$ of $\mathrm{CO}_{2}$ for $24 \mathrm{~h}$ with $30 \mathrm{~mL} / \mathrm{min}$ gas flow rate. The samples were analysed for morphology and elemental composition using FESEM-EDX model ZEISS Supram ${ }^{\mathrm{TM}} 55$.

\section{RESULTS AND DISCUSSION}

\section{CHARACTERIZATION OF ADSORBENTS}

\section{SURFACE FUNCTIONAL GROUP: FTIR SPECTROSCOPY}

Figure 1 shows the FTIR spectra of $\mathrm{ChCl}: \mathrm{U}, \mathrm{SG} 200$ and $5-15 \% \mathrm{ChCl}: \mathrm{U} / \mathrm{SG} 200$. The assignments of functional groups for each sample are provided in Table 1. The confinement of $\mathrm{ChCl}: \mathrm{U}$ into $\mathrm{SG} 200$ was confirmed by the presence of bands marked in shaded box in Figure 1 that belongs to peaks of $\mathrm{C}=\mathrm{O}$ carbonyl amide group stretching $\left(1669 \mathrm{~cm}^{-1}\right), \mathrm{N}-\mathrm{H}$ scissoring bending (1632 $\left.\mathrm{cm}^{-1}\right), \mathrm{CH}_{2}$ bending $\left(1478 \mathrm{~cm}^{-1}\right)$ and $\mathrm{C}-\mathrm{N}$ stretching (1429 $\mathrm{cm}^{-1}$ ) (Hayyan et al. 2015). As compared to IR spectrum of $\mathrm{ChCl:U}$, these bands shifted to higher wavenumber upon impregnation, possibly due to the formation of hydrogen bond between ChCl:U and SG200 (Guo et al. 2017). It is expected that $\mathrm{Cl}^{-}$anion in $\mathrm{ChCl}: \mathrm{U}$ would form hydrogen bond with silanol group in silica. Shi et al. (2005) and Zhang et al. (2009) explained that anions of IL: $\mathrm{BF}_{4}{ }^{-},(\mathrm{CN})_{2} \mathrm{~N}^{-},\left(\mathrm{CF}_{3} \mathrm{SO}_{2}\right) \mathrm{N}^{-}$and $\mathrm{CF}_{3} \mathrm{SO}_{3}^{-}$may formed hydrogen bonds with silanol group in SG. At the same time, the presence of large number of oxygen and nitrogen containing functional groups in $\mathrm{ChCl}: \mathrm{U}$ permitted the possible hydrogen bonding formation with SG. Proposed schematic illustration of interaction between SG200 and $\mathrm{ChCl}: \mathrm{U}$ is shown in Figure 2(a). The interaction is depicted from the mechanism proposed between IL and mesoporous silica (Marwani \& Alsafrani 2013).

\section{TERMAL STABILITY: TGA AND DTG THERMOGRAMS}

Figure 3 shows the TGA and DTG thermogram of SG200, $5-15 \% \mathrm{ChCl}: \mathrm{U} / \mathrm{SG} 200$. DTG curve clearly shows that the decomposition of impregnated $\mathrm{ChCl}: \mathrm{U}$ depicted the same pattern of curve with three peaks of weight loss. The first $\left(130^{\circ} \mathrm{C}\right)$ and second onset decomposition temperature $\left(210^{\circ} \mathrm{C}\right)$ belonged to the decomposition of urea. First maximum rate of decomposition occurred at $180^{\circ} \mathrm{C}$ and secondly at $240^{\circ} \mathrm{C}$. Schaber et al. (2014) investigated the decomposition of urea and reported that

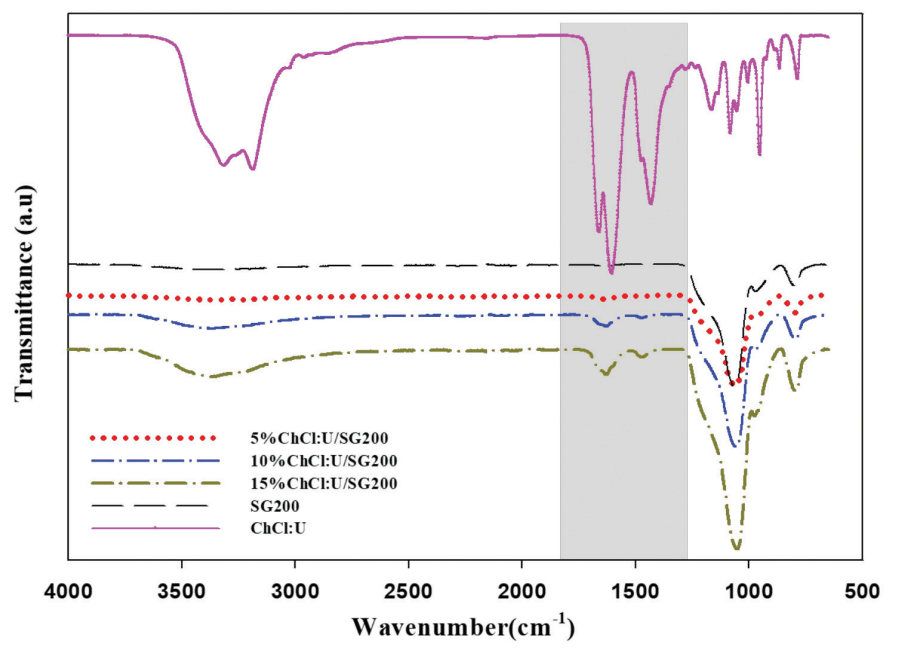

FIGURE 1. ATR-FTIR spectra for ChCl:U, SG200 and 5-15\%ChCl:U/SG200

TABLE 1. Detected FTIR peaks for ChCl:U/NS spectrum with matching functional groups and the origin

\begin{tabular}{ccc}
\hline $\begin{array}{c}\text { Wavenumber } \\
\left(\mathrm{cm}^{-1}\right)\end{array}$ & Functional group & Origin \\
\hline 1669 & $\mathrm{C}=\mathrm{O}$ stretch amide & Urea \\
1632 & $\mathrm{~N}-\mathrm{H}$ scissoring band & Urea \\
1478 & $\mathrm{CH}_{2}$ bending & $\mathrm{ChCl}$ \\
1429 & $\mathrm{C}-\mathrm{N}$ bending & Urea \\
1100 & $\mathrm{Si}-\mathrm{O}$ stretching & SG200 \\
951 & Si-OH bending & SG200 \\
793 & Si-O-Si & SG200 \\
\hline
\end{tabular}


(a)

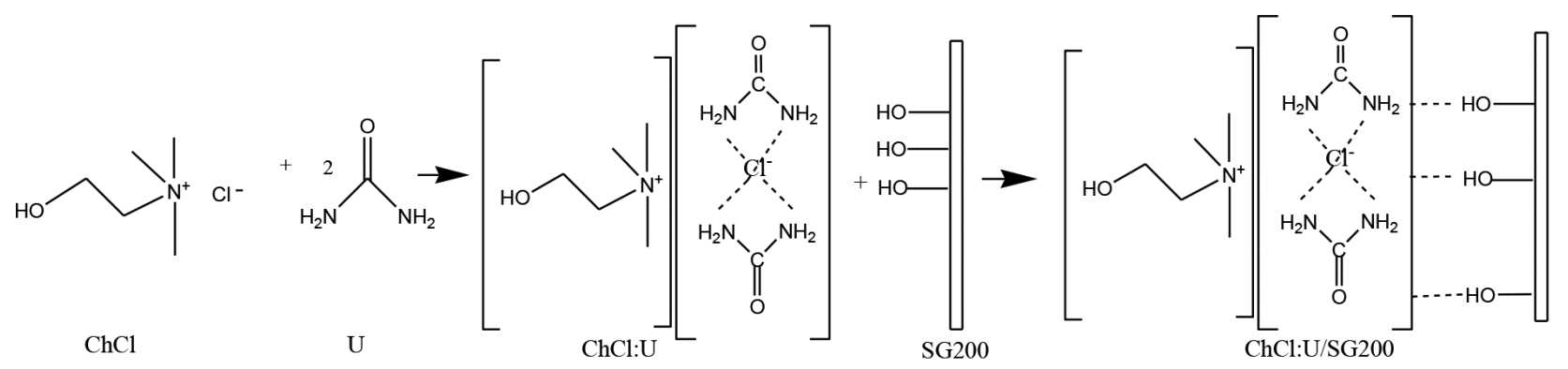

(b)

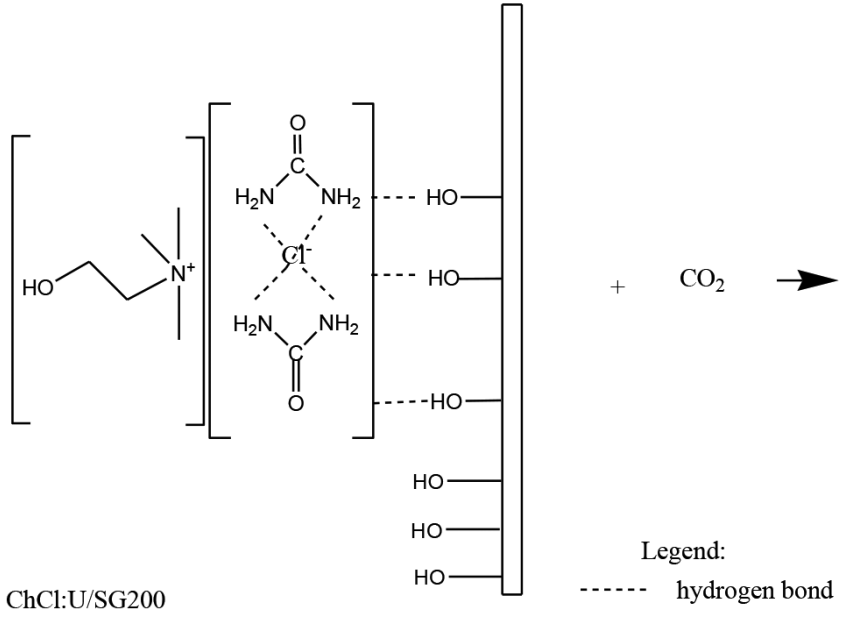

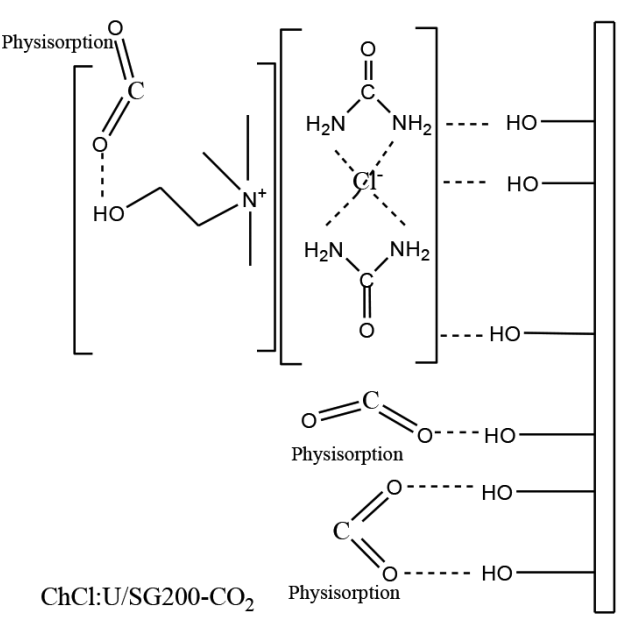

FIGURE 2. Propose schematic illustration mechanism of (a) impregnation of ChCl:U onto SG200 and (b) interaction of $\mathrm{ChCl}: \mathrm{U} / \mathrm{SG} 200$ and $\mathrm{CO}_{2}$

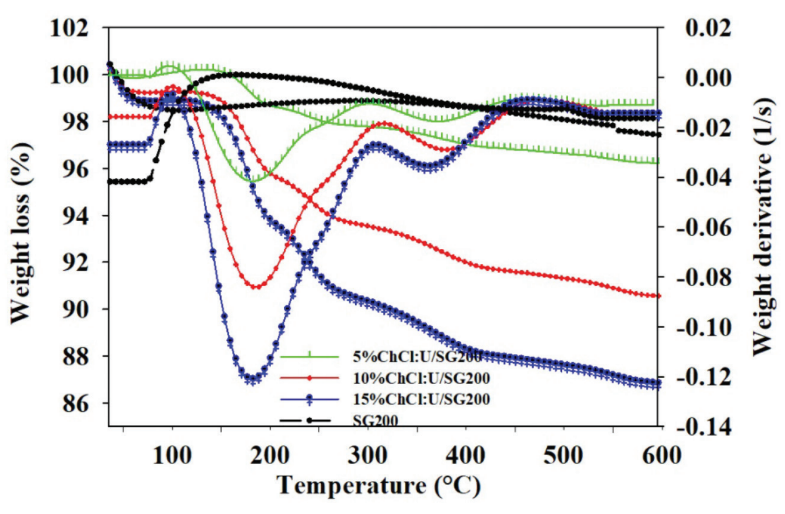

FIGURE 3. TGA and DTG thermograms for SG200 and $5-15 \% \mathrm{ChCl}: \mathrm{U} / \mathrm{SG} 200$

at first stage, $\approx 140^{\circ} \mathrm{C}$, it involved the urea vaporization. The rate of decomposition increased rapidly above $152^{\circ} \mathrm{C}$ to produce cyanic acid, ammonia and biuret. The second stage estimated $\approx 210^{\circ} \mathrm{C}$ due to the decomposition of biuret. The third onset decomposition temperature, estimated at $310^{\circ} \mathrm{C}$ belonged to decomposition of choline chloride. Urea with relatively poor thermal stability would decompose first, followed by $\mathrm{ChCl}$. However, the onset decomposition of $\mathrm{ChCl}$ was a little bit higher than pure $\mathrm{ChCl}$ which is $300^{\circ} \mathrm{C}$ (Zhang et al. 2015) due to the formation of hydrogen bond within the $-\mathrm{OH}$ from silanol group and the $\mathrm{Cl}^{-}$from $\mathrm{ChCl}$. Therefore, $5-15 \% \mathrm{ChCl}: \mathrm{U} /$ SG200 sorbents were found to be stable up to $100^{\circ} \mathrm{C}$ and heated and regenerated at $100^{\circ} \mathrm{C}$ without decomposing ChCl:U.

\section{POROSITY AND SURFACE AREA}

$\mathrm{N}_{2}$ adsorption- desorption isotherms at $77 \mathrm{~K}$ of all samples exhibited Type IV in IUPAC classification as shown in Figure 4(a), which is a common characteristic of mesoporous material with mesopores (Sing et al. 1985). These isotherms with $\mathrm{H} 2$ hysteresis were associated with capillary condensation taking place in mesopores, and the limiting uptake over a range of high relative pressure that exhibited a narrow neck and wide bodies pore of mesopores (Sing et al. 1985). The porous structures of the adsorbents were tuned by changing the weight percentage loading of ChCl:U onto SG200. This led in reducing the specific surface areas within the range of $268-333 \mathrm{~m}^{2} / \mathrm{g}$ (Table 2). Meanwhile, the average pore size of $5-15 \% \mathrm{ChCl}: \mathrm{U} / \mathrm{SG} 200$ (6.60-6.50 nm) were larger compared to the average pore size of the support SG200 $(6.20 \mathrm{~nm})$. This may suggest the $\mathrm{ChCl}: \mathrm{U}$ loaded on the $\mathrm{SG} 200$ with uneven distribution creating its own structure with larger neck widths (Wang et al. 2012).

Smaller average pore diameter for $15 \% \mathrm{ChCl}$ :U loading compared to $5 \%$ and $10 \%$ results from more pore filling 
and thickening of $\mathrm{ChCl}: \mathrm{U}$ layer on SG200. These results indicated that mesopores of the support were blocked or covered at higher $\mathrm{ChCl}: \mathrm{U}$ loading that led to decrease in surface area. It is suggested that during impregnation process, the $\mathrm{ChCl}: \mathrm{U}$ was first distributed in the micropores and mesopores channels in the SG200 skeleton until it was filled. Further loading, $\mathrm{ChCl}: \mathrm{U}$ coated the external surface of the supporter frameworks (Abu Tahari et al. 2015; Guo et al. 2017).
All sorbents showed large pore size distribution that

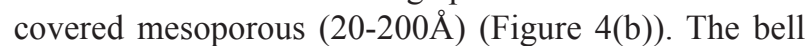
shape of the distribution is smaller for $15 \% \mathrm{ChCl}: \mathrm{U} / \mathrm{SG} 200$ with several small sharp peaks on SG200 at two pores, 86 $\AA$ and $100 \AA$ in diameter, were diminished. This result supported the aforementioned statement that part of the mesopores were blocked. It also suggested that $\mathrm{ChCl:U}$ can easily enter narrow pore structure leading to pore filling completely.

a)

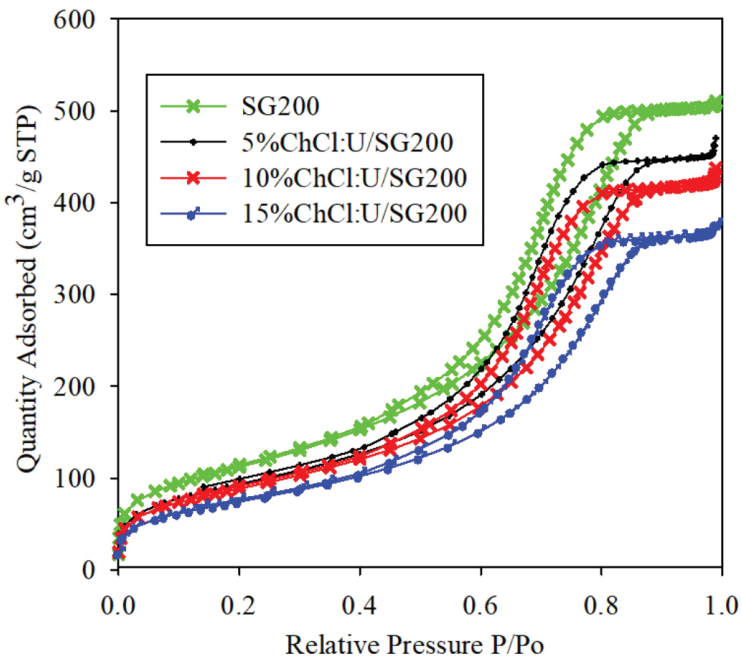

b)

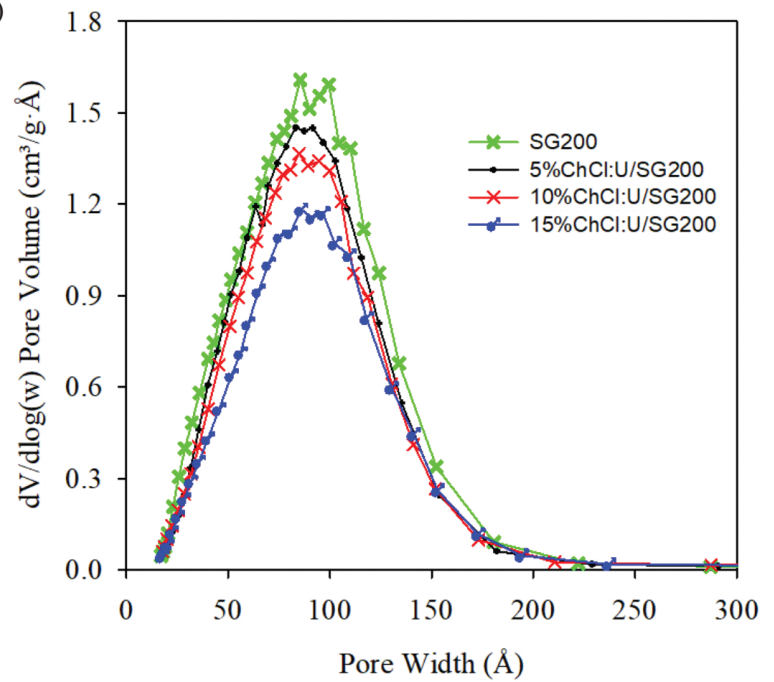

FIGURE 4. a) $\mathrm{N}_{2}$ adsorption and desorption isotherm b) pore size distribution for SG200 and 5-15\% ChCl:U/SG200

TABLE 2. Physical properties for SG200 and 5-15\% ChCl:U/SG200

\begin{tabular}{lcccc}
\hline Adsorbents & $\begin{array}{c}\mathrm{S}_{\text {BET }} \\
\left(\mathrm{m}^{2} / \mathrm{g}\right)\end{array}$ & $\begin{array}{c}\mathrm{S}_{\text {t-plotexternal }} \\
\left(\mathrm{m}^{2} / \mathrm{g}\right)\end{array}$ & $\begin{array}{c}\mathrm{V}_{\text {total }} \\
\left(\mathrm{cm}^{3} / \mathrm{g}\right)\end{array}$ & $\begin{array}{c}\text { Average pore size } \\
(\mathrm{nm})\end{array}$ \\
\hline SG200 & 397.8 & 399.3 & 0.78 & 6.20 \\
$5 \% \mathrm{ChCl}: \mathrm{U} / \mathrm{SG} 200$ & 333.0 & 353.4 & 0.73 & 6.60 \\
10\%ChCl:U/SG200 & 317.5 & 338.8 & 0.65 & 6.54 \\
15\%ChCl:U/SG200 & 268.0 & 286.8 & 0.56 & 6.50 \\
\hline
\end{tabular}




\section{$\mathrm{CO}_{2}$ ADSORPTION STUDY}

Figure 5(a) and 5(b) shows the $\mathrm{CO}_{2}$ adsorption isotherm and $\mathrm{CO}_{2}$ maximum adsorption capacity for all samples at $25^{\circ} \mathrm{C}, 1 \mathrm{~atm}$ pressure and $99 \% \mathrm{CO}_{2}$. The adsorption capacity of SG200 is improved after $\mathrm{ChCl}: \mathrm{U}$ impregnation. SG200 managed to adsorb more $\mathrm{CO}_{2}(20.3 \mathrm{mg} / \mathrm{g})$ as a result of physical adsorption between $\mathrm{CO}_{2}$ and SG200. The $\mathrm{CO}_{2}$ uptake was being governed by the accessible mesopores in which the $\mathrm{CO}_{2}$ was trapped in mesopores and might form hydrogen bond with silanol group (Zhang et al. 2009). With $5 \%$ and $10 \% \mathrm{ChCl}: \mathrm{U}$ loading, the $\mathrm{CO}_{2}$ adsorption capacity increased up to 21.3 and $22.3 \mathrm{mg} / \mathrm{g}$, respectively, indicating that the impregnated $\mathrm{ChCl}: \mathrm{U}$ onto $\mathrm{SG} 200$ can capture $\mathrm{CO}_{2}$ effectively. It suggested that increment of $\mathrm{ChCl}$ : $\mathrm{U}$ loading up to $10 \%$ covered the external and internal pore surface area hence leading to the occurrence of more interaction between $\mathrm{ChCl}: \mathrm{U}$ and $\mathrm{CO}_{2}$. Higher loading of $\mathrm{ChCl}: \mathrm{U}$ up to $15 \%$ did not show significant impact to the overall $\mathrm{CO}_{2}$ uptake but negatively causing extreme decreased in $\mathrm{CO}_{2}$ adsorption capacity to $19.7 \mathrm{~m} / \mathrm{g}$. Excess $\mathrm{ChCl}: \mathrm{U}$ to $15 \%$ loading has blocked the SG200 mesopores, hence the $\mathrm{CO}_{2}$ could not diffuse inside the pore (Lee et al. 2014). It can be seen from the steep reduction of the surface area and pore volume for $15 \% \mathrm{ChCl}: \mathrm{U} / \mathrm{SG} 200$. As a result, we can conclude that $10 \% \mathrm{ChCl}: \mathrm{U} / \mathrm{SG} 200$ gave the highest $\mathrm{CO}_{2}$ adsorption capacity.

Figure 6 shows the $10 \% \mathrm{ChCl}: \mathrm{U} / \mathrm{SG} 200$ morphology before and after adsorption of $\mathrm{CO}_{2}$ using FESEM with expansion of $10000 \mathrm{~K}$ and elemental analysis using EDX. The SG200 surface was covered with $\mathrm{ChCl}$ : U, therefore, the presence of the pore on the surface of SG200 could not be clearly seen. There were unclear changes in the sample structure before and after the adsorption of $\mathrm{CO}_{2}$. EDX analysis showed that the $\mathrm{CO}_{2}$ adsorption occurred when the percentage of atom $\mathrm{C}$ and $\mathrm{O}$ percentages were increased after $\mathrm{CO}_{2}$ exposure.

It was suggested that the main adsorption is physisorption in which the trapped $\mathrm{CO}_{2}$ formed hydrogen bond with the $-\mathrm{OH}$ from SG200 silanol group. Figure 2(b) shows the suggested reaction mechanism of the $\mathrm{CO}_{2}$ sorption on $\mathrm{ChCl}: \mathrm{U} / \mathrm{SG} 200$. There is also a slight possibility of chemical reaction occurrence due to a long period exposure with $\mathrm{CO}_{2}(24 \mathrm{~h})$ which need more supported evidence from analysis result. The information about mechanism involved is still limited and need to be explored.

a)

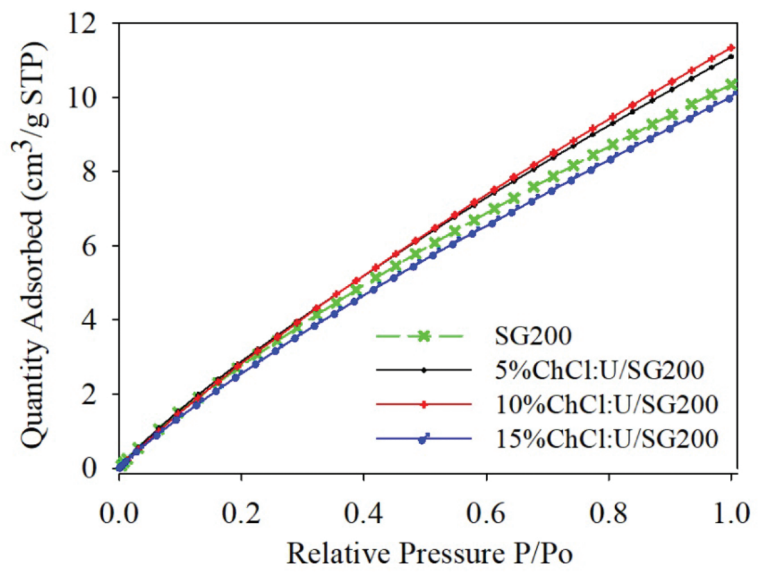

b)

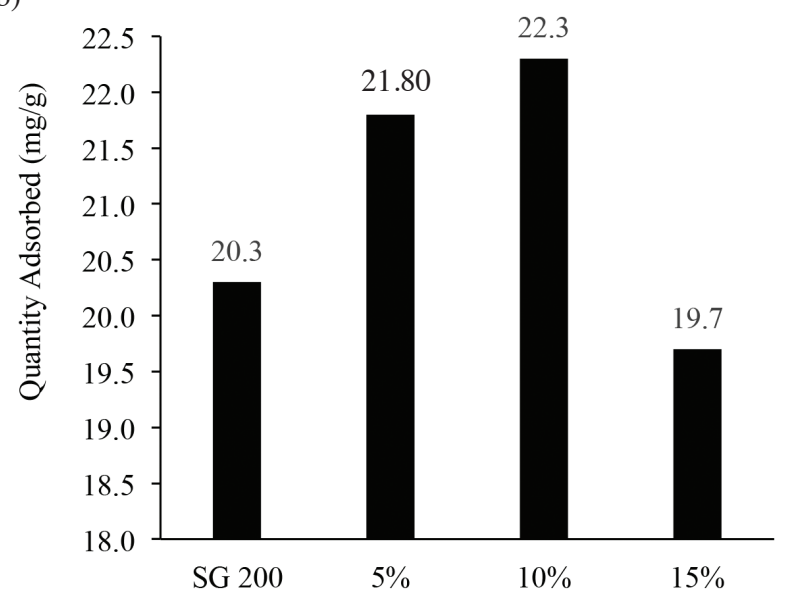

FIGURE 5. (a) $\mathrm{CO}_{2}$ adsorption isotherm and (b) $\mathrm{CO}_{2}$ maximum adsorption capacity for $\mathrm{SG} 200,5-15 \% \mathrm{ChCl}: \mathrm{U} / \mathrm{SG} 200$ 

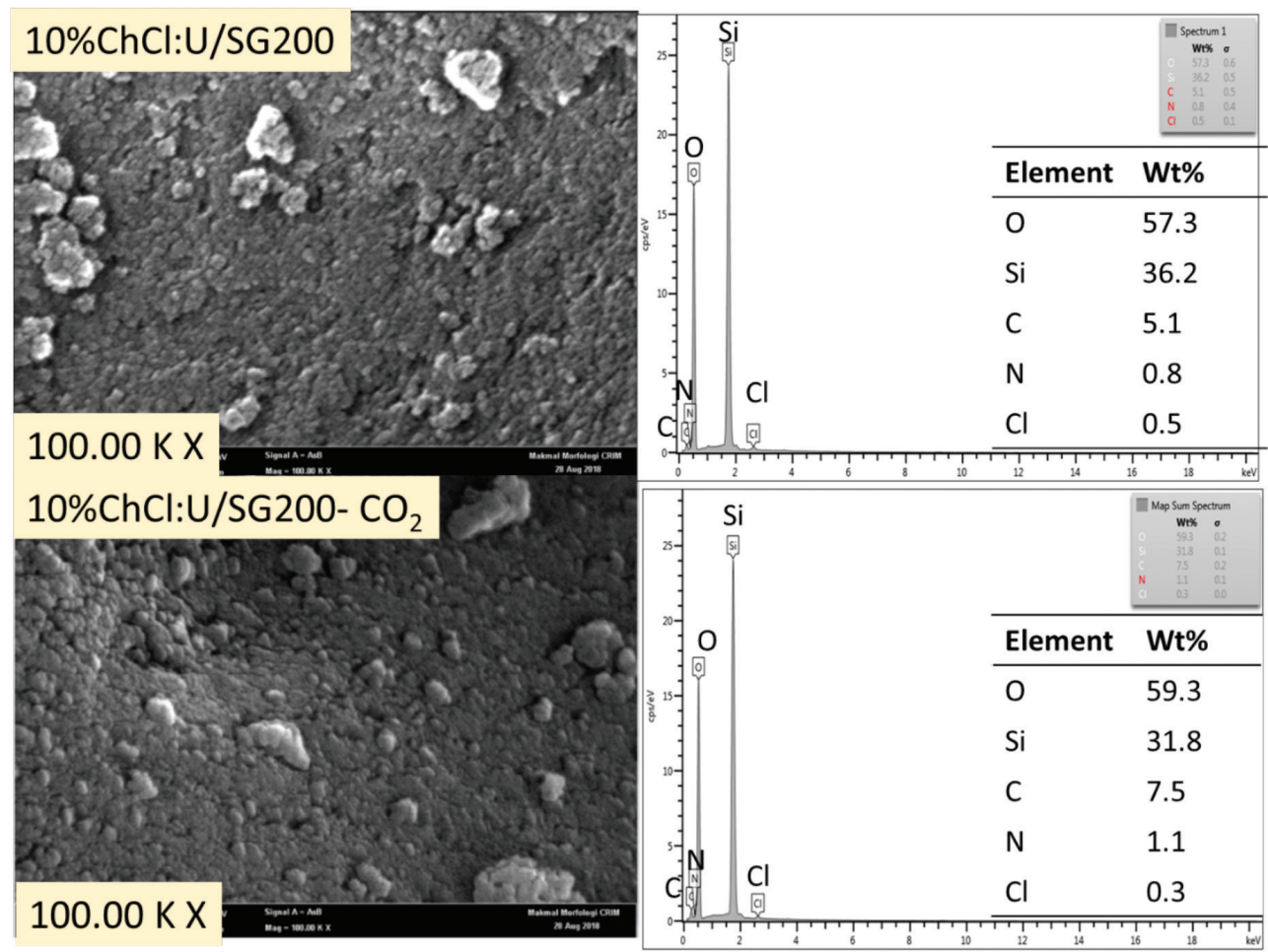

FIGURE 6. FESEM micrograph and EDX analysis for $10 \% \mathrm{ChCl}: \mathrm{U} / \mathrm{SG} 200$ a) before exposure with $\mathrm{CO}_{2}$ and b) after exposure with $\mathrm{CO}_{2}$ at magnifying scale $10000 \mathrm{~K}$

TABLE 3. Adsorption capacity of $\mathrm{ChCl:U}$ and ILs as comparison

\begin{tabular}{lcccl}
\hline Solvent/supporter & $\begin{array}{c}\mathrm{T} \\
(\mathrm{K})\end{array}$ & $\begin{array}{c}\mathrm{P} \\
(\mathrm{MPa})\end{array}$ & $\begin{array}{c}\mathrm{CO}_{2} \mathrm{ACp} \\
(\mathrm{mg} / \mathrm{g})\end{array}$ & References \\
\hline $10 \% \mathrm{ChCl}: \mathrm{U} / \mathrm{SG} 200$ & 303 & 0.101 & 22.3 & This work \\
$\mathrm{ChCl}:$ Ethylene $\mathrm{glycol} / \mathrm{AC}$ & 303 & 0.101 & 9.8 & Zulkurnai et al. 2017 \\
$10 \%\left[\right.$ Emim] $\left[\mathrm{H}_{\mathrm{S}} \mathrm{O}_{4}\right] / \mathrm{SiO}$ & 298 & 0.101 & 26.7 & Marliza et al. 2017 \\
$16 \%[$ Emim] $][\mathrm{Gly}] / \mathrm{Y}-\mathrm{Al}_{2} \mathrm{O}_{3}$ & 303 & 0.101 & 25.0 & Balsamo et al. 2018 \\
$16 \%[$ Emim] $[\mathrm{Gly}] / \mathrm{AC}$ & 303 & 0.101 & 17.2 & Erto et al. 2015 \\
\hline
\end{tabular}

*AC $=$ activated carbon (Filtrasorb 400), $\mathrm{T}=$ Temperature, $\mathrm{P}=$ Pressure, $\mathrm{ACp}=$ Adsorption Capacity

The adsorption capacity of $10 \% \mathrm{ChCl}: \mathrm{U} / \mathrm{SG} 200$ from this study was compared with the adsorption of supported $\mathrm{ChCl}: \mathrm{U}$ and ILs obtained from literatures as shown in Table 3 . The adsorption capacity of $10 \% \mathrm{ChCl}: \mathrm{U} /$ SG200 was comparable to IL $[\mathrm{Emim}]\left[\mathrm{H}_{2} \mathrm{SO}_{4}\right] / \mathrm{SiO}$ and $[$ Emim] $] \mathrm{Gly}] / \Upsilon-\mathrm{Al}_{2} \mathrm{O}_{3}$ although the supporters used $\left(\mathrm{SiO}\right.$ and $\mathrm{Y}-\mathrm{Al}_{2} \mathrm{O}_{3}$ ) had larger surface area. Furthermore, adsorption capacity of $10 \% \mathrm{ChCl}: \mathrm{U} / \mathrm{SG} 200$ was better than $\mathrm{ChCl}: \mathrm{U}$ and [Emim] [Gly] supported activated carbon. These results showed $10 \% \mathrm{ChCl}: \mathrm{U} / \mathrm{SG} 200$ adsorbent as a potential candidate for $\mathrm{CO}_{2}$ capture alternative as its adsorption capacities were higher than the nonfunctionalised SG200. The ability and effectiveness of this adsorbent in capturing $\mathrm{CO}_{2}$ at room temperature $25^{\circ} \mathrm{C}$ and atmospheric pressure $1 \mathrm{~atm}$ making it a practical material for $\mathrm{CO}_{2}$ capture.

\section{CONCLUSION}

In this work, choline chloride:urea $(\mathrm{ChCl}: \mathrm{U})$ impregnated onto silica gel (SG) was synthesized as a new green solid adsorbent for $\mathrm{CO}_{2}$ capture. The $10 \%$ addition of $\mathrm{ChCl}: \mathrm{U}$ onto SG was the optimum ratio with the highest $\mathrm{CO}_{2}$ adsorption capacity of $22.3 \mathrm{mg} / \mathrm{g}$. The adsorption of $\mathrm{CO}_{2}$ in impregnated $\mathrm{ChCl}: \mathrm{U}$ was found to be comparable with other impregnated liquid adsorbents. Therefore, $10 \% \mathrm{ChCl}: \mathrm{U} / \mathrm{SG} 200$ could be regarded as a promising adsorbent for $\mathrm{CO}_{2}$ capture at room temperature and atmospheric pressure.

\section{ACKNOWLEDGEMENTS}

The authors would like to acknowledge Universiti Kebangsaan Malaysia (UKM) for funding this project under 
research grants of ST-2017-008 and FRGS/1/2017/STG01/ UKM/02/5, Polymer Research Centre (PORCE) for technical support and Centre for Research and Instrumentation Management (CRIM) for the instrument facilities.

\section{REFERENCES}

Abu Tahari, M.N., Hakim, A., Wan Isahak, W.N.R., Samad, W.Z. \& Yarmo, M.A. 2015. Adsorption of $\mathrm{CO}_{2}$ on OctadecylamineImpregnated on $\mathrm{SiO} 2$ : Physical and chemical interaction studies. Advanced Materials Research 1087: 137-141.

Balsamo, M., Erto, A., Lancia, A., Totarella, G., Montagnaro, F. \& Turco, R. 2018. Post-combustion $\mathrm{CO}_{2}$ capture: On the potentiality of amino acid ionic liquid as modifying agent of mesoporous solids. Fuel 218(April 2017): 155-161.

Creamer, A.E. \& Gao, B. 2015. Carbon Dioxide Capture: An Affective Way to Combat Global Warming. New York: Springer Berlin Heidelberg.

Dai, Y., Van Spronsen, J., Witkamp, G., Verpoorte, R. \& Choi, Y.H. 2013. Ionic liquids and deep eutectic solvents in natural products research: Mixtures of solids as extraction solvents. Journal of Natural Product 76: 2162-2173.

Erto, A., Silvestre-albero, A., Silvestre-albero, J., Rodríguezreinoso, F., Balsamo, M., Lancia, A. \& Montagnaro, F. 2015. Carbon-supported ionic liquids as innovative adsorbents for $\mathrm{CO}_{2}$ separation from synthetic flue-gas. Journal of Colloid and Interface Science 448: 41-50.

Gray, M.L., Champagne, K.J., Fauth, D., Baltrus, J.P. \& Pennline, H. 2012. Performance of immobilized tertiary amine solid sorbents for the capture of carbon dioxide. International Journal of Greenhouse Gas Control 2(2008): 3-8.

Guo, X., Ding, L., Kanamori, K., Nakanishi, K. \& Yang, H. 2017. Functionalization of hierarchically porous silica monoliths with polyethyleneimine (PEI) for $\mathrm{CO}_{2}$ adsorption. Microporous and Mesoporous Materials 245: 51-57.

Hayyan, M., Abo-Hamad, A., AlSaadi, M.A. \& Hashim, M.A. 2015. Functionalization of graphene using deep eutectic solvents. Nanoscale Research Letters 10(1): 2-26.

Hu, J., Yang, X., Yu, J. \& Dai, G. 2017. Carbon dioxide (CO2) absorption and interfacial mass transfer across vertically confined free liquid film-a numerical investigation. Chemical Engineering \& Processing: Process Intensification 111: 46-56.

Jon, N., Abdullah, I. \& Othaman, R. 2013. Effects of silica on the formation of epoxidised natural rubber/polyvinyl chloride membrane. Sains Malaysiana 42(4): 469-473.

Lee, C.H., Hyeon, D.H., Jung, H., Chung, W., Jo, D.H., Shin, D.K. \& Kim, S.H. 2014. Effects of pore structure and PEI impregnation on carbon dioxide adsorption by ZSM-5 zeolites. Journal of Industrial and Engineering Chemistry 23: 251-256.

Leron, R.B. \& Li, M.H. 2013. Solubility of carbon dioxide in a choline chloride-ethylene glycol based deep eutectic solvent. Thermochimica Acta 551: 14-19.

Leron, R.B., Caparanga, A. \& Li, M.H. 2013. Carbon dioxide solubility in a deep eutectic solvent based on choline chloride and urea at $\mathrm{T}=303.15-343.15 \mathrm{~K}$ and moderate pressures. Journal of the Taiwan Institute of Chemical Engineers 44(6): 879-885.

Marcus, Y. 2018. Gas solubilities in deep eutectic solvents. Monatshefte Fur Chemie 149(2): 211-217.
Marliza, T.S., Yarmo, M.A., Hakim, A., Tahari, M.N.A., Hisham, M.W.M. \& Taufiq-Yap, Y.H. 2017. $\mathrm{CO}_{2}$ capture on $\mathrm{NiO}$ supported imidazolium-based ionic liquid. American Institute of Physics 20008: 1-8.

Marwani, H.M. \& Alsafrani, A.E. 2013. New solid phase extractor based on ionic liquid functionalized silica gel surface for selective separation and determination of lanthanum. Journal of Analytical Science and Technology 4(1): 13.

Ramdin, M., De Loos, T.W. \& Vlugt, T.J.H. 2012. State-of-the-art of $\mathrm{CO}_{2}$ capture with ionic liquids. Industrial and Engineering Chemistry Research 51: 8149-8177.

Rao, S. \& Riahi, K. 2006. The role of non-CO2 greenhouse gases in climate change mitigation: Long-term scenarios for the 21st century. Energy Journal 27: 177-200.

Sarmad, S., Mikkola, J.P. \& Ji, X. 2017. Carbon dioxide capture with ionic liquids and deep eutectic solvents: A new generation of sorbents. ChemSusChem 10(2): 324-352.

Schaber, P.M., Colson, J., Higgins, S., Thielen, D., Anspach, B. \& Brauer, J. 2004. Thermal decomposition (pyrolysis) of urea in an open reaction vessel. Thermochimica Acta 424(1-2): 131-142.

Shi, F., Zhang, Q., Li, D. \& Deng, Y. 2005. Silica-gel-confined ionic liquids: A new attempt for the development of supported nanoliquid catalysis. Chemistry - A European Journal 11(18): 5279-5288.

Sing, S.W.K., Everett, D.H., Haul, R.A.W., Moscou, L., Pierotti, R.A., Rouquerol, J. \& Siemieniewska, T. 1985. Reporting physisorption data for gas/solid systems. Pure Applied Chemistry 57: 603-619.

Vilarrasa-García, E., Cecilia, J.A., Santos, S.M.L., Cavalcante, C.L., Jiménez-Jiménez, J., Azevedo, D.C.S. \& RodríguezCastellón, E. 2014. $\mathrm{CO}_{2}$ adsorption on APTES functionalized mesocellular foams obtained from mesoporous silicas. Microporous and Mesoporous Materials 187: 125-134.

Wang, K., Shang, H., Li, L., Yan, X., Yan, Z., Liu, C. \& Zha, Q. 2012. Efficient $\mathrm{CO}_{2}$ capture on low-cost silica gel modified by polyethyleneimine. Journal of Natural Gas Chemistry 21(3): 319-323.

Yu, B., Cong, H., Zhao, X.S. \& Chen, Z. 2011. Carbon dioxide capture by Dendrimer-modified silica nanoparticles. Adsorpt. Sci. Technol. 29(8): 781-788.

Yusuf, N.Y.M., Masdar, M.S., Isahak, W.N.R.W. \& Nordin, D. 2018. Impregnated carbon- ionic liquid as innovative adsorbent for $\mathrm{H}_{2} / \mathrm{CO}_{2}$ separation from biohydrogen. International Journal of Hydrogen Energy 44(6): 3414-3424.

Zhang, J., Ma, Y., Shi, F., Liu, L. \& Deng, Y. 2009. Room temperature ionic liquids as templates in the synthesis of mesoporous silica via a sol-gel method. Microporous and Mesoporous Materials 119(1-3): 97-103.

Zhang, Y., Ji, X. \& Lu, X. 2015. Choline-based deep eutectic solvents for mitigating carbon dioxide emissions. Novel Materials for Carbon Dioxide Mitigation Technology, edited by Shi, F. \& Morreale, B. New York: Elsevier B.V. pp. 87-116.

Zhu, J., He, B., Huang, J., Li, C. \& Ren, T. 2018. Effect of immobilization methods and the pore structure on $\mathrm{CO}_{2}$ separation performance in silica-supported ionic liquids. Microporous and Mesoporous Materials 260(October 2017): 190-200.

Zhu, J., Xin, F., Huang, J., Dong, X. \& Liu, H. 2014. Adsorption and diffusivity of $\mathrm{CO}_{2}$ in phosphonium ionic liquid modified silica. Chemical Engineering Journal 246: 79-87. 
Zaitun Ghazali, Nur Hasyareeda Hassan, Mohd Ambar Yarmo, Teh Lee Peng \& Rizafizah Othaman*

School of Chemical Sciences and Food Technology

Faculty of Science and Technology

Universiti Kebangsaan Malaysia

43600 UKM Bangi, Selangor Darul Ehsan

Malaysia

Zaitun Ghazali, Nur Hasyareeda Hassan \& Rizafizah Othaman* Polymer Research Center

Faculty of Science and Technology

Universiti Kebangsaan Malaysia

43600 UKM Bangi, Selangor Darul Ehsan

Malaysia
Mohd Ambar Yarmo \& Teh Lee Peng

Catalyst Research Group

Faculty of Science and Technology

Universiti Kebangsaan Malaysia

43600 UKM Bangi, Selangor Darul Ehsan

Malaysia

*Corresponding author; email: rizafizah@ukm.edu.my

Received: 7 February 2019

Accepted: 28 March 2019 